\title{
14
}

\section{Afterword: Reflections on Nationalism}

\author{
Peter van der Veer
}

One of the things that has become clear during the COVID-19 pandemic of 2020 and 2021 is that nation states were the first responders to this global threat, not supranational organizations. If the paramount authority of the nation state was ever in doubt, it is not anymore. The European Union, the most ambitious supranational political organization in the world today, quickly dissolved into a conglomerate of seemingly unconnected and competing nation states. Something similar had happened when large groups of Syrian and other refugees crossed the European borders in 2015 (Meyer and van der Veer 2021). Every country in the European Union developed its own political response, just as in the case of the pandemic. Not only has the nation state organized the response to COVID-19, the cultural interpretation of the origins and spread of this virus is couched in nationalist terms. US President Trump and his followers talked about the Wuhan virus, while the Chinese authorities

P. van der Veer $(\bowtie)$

Max Planck Institute for the Study of Religious and Ethnic Diversity,

Göttingen, Germany

e-mail: vanderVeer@mmg.mpg.de 
hid their slow and inadequate response to the early spread of the virus and turned the subsequent containment of it into a narrative of the victory of the Chinese political model. Even the global scientific triumph of creating several vaccines has been transmogrified into a tale of nationalist chauvinism and competition.

Slowly but perhaps inescapably the liberal and leftist belief in some form of European cosmopolitanism has become marginal. The Euroscepticism of Perry Anderson (2021) and Jürgen Streeck (2017) have replaced Jürgen Habermas' (2012) critical support of a unified Europe. The political right has always been more comfortable with nationalism and sceptical of anything beyond free trade. The biggest political challenge in Europe, North America and Australia today, however, is not nationalism but its close cousin, anti-immigrant populism. The leading opposition parties in France, Italy, Germany and the Netherlands exemplify this kind of populism, while in the UK and Hungary the ruling parties derive their power from it. These parties and movements are not anti-democratic, but they try to simplify who the 'demos' is. The political signification of 'the people' may be shifting. For example, the slogan 'Wir sind das Volk' ('We are the People') in Eastern Germany shifted from being against the communist state to being against the post-unification, democratic state. Here, as in the case of the Turkish President Erdogan's slogan 'We are the people. Who are you?', the question is indeed who is the demos in the democratic 'will of the people'. Better yet is the question of who does not belong to 'the people', such as Kurds in Turkey, Uyghur in China or Muslims in India. Much populism turns around a rhetoric of accusing elites of grabbing power for special interest instead of the people's interest ('draining the swamp of Washington'), but when they gain power (Trump, Erdogan, Modi, Duterte and others) they themselves become such political elites (Müller 2016). Once they have gained power, they can only hold on to it by accusing dark forces (foreign or domestic) of illegitimately threatening the nation. Violence used to hold on to power is then portrayed as a defence of the nation, a vivid example of which was shown in the attack on Capitol Hill in the US by Trump supporters. Populism de-legitimizes the state in the name of an invisible nation or a silent majority. Its vision is unitary and pure and thus requires constant purification. 
While populism is an aspect of the modern quest for 'the true, pure nation', ethnic cleansing and religious purification have a long history as part of modern state formation in Europe. The Reformation stands out as the first period in European and possibly global history in which the religious refugee becomes a mass phenomenon. The Puritans exiled themselves to America, and the Anabaptists, the Huguenots and everyone else moved around in the several wars of religion that followed the Reformation. As the historian Nicholas Terpstra (2015) argues, the Reformation was not just a movement for intellectual and religious change. It was also Europe's first grand project in social purification. It was deeply about exile, expulsion and refugees. Forced religious migration was a normal, familiar and expected feature of public policy that was oriented to building a cohesive society. The formula cuius regio, eius religio, stating that the people have to follow the religion of their rulers, was a principle that legitimized a combination of migration and war. At the end of the Thirty Years War, the Peace of Westphalia in 1648 built a fragile international system to deal with the treatment of minorities.

José Casanova (2019: 14-15) has recently argued that 'everywhere one finds similar processes of state-led confessionalization: Northern Europe becomes homogeneously Protestant, Southern Europe becomes homogeneously Catholic and in between one finds three bi-confessional societies-Holland, Germany and Switzerland — unable to eliminate the other religious half, having to co-exist, and developing their own patterns of Protestant-Catholic confessionalization: confessional pillars in the case of Holland, confessional Länder in the case of Germany, and confessional cantons in the case of Switzerland'.

In 1960s Netherlands, the postwar generation began to demolish this system of religious and ideological pacification, and unchurching was accompanied with radical critiques of religion (see Verkaaik in this volume). In 2018, only 9 per cent of the Dutch population were still members of a church. In a few decades, Dutch society, which until the 1960s had been dominated by religious communities, was secularized. This massive transformation was connected with the emergence of the welfare state in the 1950s and the youth revolution of the 1960s, but not, as 
modernization theory had it, with industrialization and urbanization, nor with the constitutional separation of church and state, which in the Netherlands were nineteenth-century phenomena. All three components of the secularization thesis-differentiation of the secular spheres from religious norms and institutions, decline of religious beliefs and practices, and privatization of the religious sphere-could be found in the Netherlands, but not as a result of the emergence of a modern state, modern economy or modern science. In fact, we could argue that the modernization of the Netherlands resulted for almost a century in an increase in the societal and political relevance of religion, as shown, for example, in the foundation of a Protestant Free University in Amsterdam (1880) and a Catholic University in Nijmegen (1923). The mobilization of religious identities in the formation of the Dutch nation triggered not only bi-polar competition between Catholics and Protestants, but also a heightened intensity of theological debate, especially among Protestants. The rapid secularization of Dutch society is not generalizable. Nevertheless, until today many intellectuals in the Netherlands have the firm conviction that secularization is a teleological process of modern change. Leading sociologists in the Netherlands, like Johan Goudsblom and Abram de Swaan, following Norbert Elias, saw the global fading away of religion as inevitable. The visceral distaste for religion among Dutch intellectuals who came of age in the 1960s explains today's widespread view of Islam as 'a backward religion' that is incommensurable with modern Dutch values, especially in the sexual sphere. Casanova (2006: 17) puts it succinctly: 'in such a context, the study of modern secularism, as an ideology, as a generalized worldview, and as a social movement, and of its role as a crucial carrier of processes of secularization and as a catalyst for counter-secularization responses should be high on the agenda of a self-reflexive comparative historical sociology of secularization'. As Oskar Verkaaik (this volume) shows, it is specifically in Dutch literature that one finds the contestation of religious identity in terms of sexual liberation, from the erotic mysticism of Gerard Reve to the transgendered lyricism of Lucas Maria Rijneveld.

Consensual distancing between religious groups was the preferred mode of co-existence in the Netherlands. Under the influence of the Dutch Reformed Church, this was transformed into non-consensual 
apartheid in South Africa. As Shaheed Tayob shows in this volume, in post-apartheid South Africa the legacy of social distancing is found in fascinating contestations of control over public space. In many other societies, the idea of purification by expulsion became a legitimate aspect of statecraft, combining ethnic and religious cleansing. In the German case, Lutheran Protestantism became a dominant part of German nationalism in the nineteenth century, while the Catholics had to show their loyalty to the state. However, one does not need religion for the cleansing of the nation. The two competing totalitarian ideologies of the twentieth century, Nazism and Communism, were atheistic but very much into ethnic cleansing in which religion was a significant element, but race paramount. The collapse of the Habsburg Empire and Czarist Russia gave rise to an unprecedented un-mixing of populations. Cleansing took place by both expulsion and extermination. From 1933 to 1945, Nazi and Soviet regimes murdered fourteen million people between Berlin and Moscow, quite apart from the war dead (Snyder 2010). These were all civilians, abandoned to state power, which reminds us that the state protects some but attacks others and that mass murder and massive forced migration are nothing new to Europe. The idea that European nation states are stable democracies is a fiction that could only be maintained during the Cold War when geopolitical forces kept the West and the East under tight control. After the fall of the Berlin Wall in 1989, this fiction was largely based on Germany's wish to be a stabilizing and unifying force in Europe and on the military hegemony of the US. The global economic crisis of 2008 has shown how fragile this unity was. The decline of trust in the European Union and the rise of anti-Europe populism are, at least partly, the long-term results of the handling of the financial crisis.

Imaginings of nationhood emerged in early modern Europe in the context of drawing ethno-religious boundaries between Christians, Muslims and Jews. This happened in the same period as the IberianCatholic expansion over the world. A moment of particular interest in the European history of state formation is the expulsion of Muslims and Jews after centuries of convivencia from the Catholic nación of Spain. In 1492, Columbus records in his logbook that he sees the boats of Muslims and Jews leaving the shores of Spain while he goes out to discover the New World. This signifies a major shift in the history of the modern 
world, one that combines the religious purification of the Spanish nation with the expansion of that nation's religion over the world.

A crucial aspect of the history of imperial formations is the history of conversion. Probably Japan showed the strongest response to Christian conversion. The Jesuits entered it in 1549, supported by the Portuguese. At the end of the sixteenth century, however, after the crucifixion of 26 priests and converts, Japanese were asked to register as Buddhists. Only pockets of surviving hidden Christians, similar to Marranos in Spain, stayed on in Japan, constantly fearing questioning about their beliefs. This confessionalization of the Japanese state and the cleansing of the Christian minority bear a stark resemblance to European history. Japan's nationhood and its state control over religious belief emerged from the purging of Christianity.

It is the unending work of purification that gives rise to the Inquisition, an institution that spread beyond Europe to areas like the Philippines and Mexico, where Spanish or Portuguese power was consolidated. When that power could not be established as in China (except for Macau), India (except for Goa) and Japan, the rulers in those places had to be convinced that Christianity was not a threat to their power. The Jesuits did that successfully in China from the sixteenth century until the early eighteenth century, when Pope Clement refused to allow Chinese Christians to conduct Confucian rituals or ancestral rituals. In 1721 Emperor Kangxi of China responded by banning Christian missions from China, a ban upheld by the Qing emperors until the Opium Wars of the midnineteenth century. The European imperial powers forced the Qing government not only to accept the sale of opium by European traders, but also the propagation of Christianity by European missionaries. This forced entry of Christian missionaries is today still regarded in China as a sign of the indelible connection between Western imperialism and Christianity. The refusal by the Pope to accept control over the Church by the Chinese state authorities after 1949 sounds like an echo from the past, as are the Papacy's most recent attempts to find a middle ground between Chinese state hegemony and the Church's autonomy.

In nineteenth-century India under British colonial rule, missionaries targeted primarily marginal groups, like untouchables and the tribal populations, especially by offering education and medical care. After 
Independence, this came to be seen as an imperialist strategy to divide the Hindu nation. Conversion to Christianity was now made very difficult through legislation that allowed it only for adults with written affidavits. When Amartya Sen received the Noble Prize for Economics in 1998, Ashok Singhal, the then president of the Vishwa Hindu Parishad (World Hindu Assembly), commented that awarding this Nobel Prize to Sen was a Christian conspiracy against the nation and that Sen's developmental strategy to promote literacy was connected to Christian missionary efforts to proselytize under the cover of education. For the Hindu nationalists, Christian schools are covers for religious conversion. The Bible classes for Chinese children in Berlin, described by Yu in this volume, seem to illustrate that possibility.

The formation of nation states and the culture of nationalism are not only aspects of the gradual expansion of industrial society (Gellner 1983) or of novel imaginations enabled by technologies of communication (Anderson 1991). It is deeply violent in its targeting of enemies both within the population and outside it. It derives its social energy from being an always unfinished project, constantly re-defining 'we' and 'others' (Verkaaik 2004). In an important study of Muslim politics in India, Irfan Ahmad (2009) has shown that, after the fratricidal bloodshed of the Partition, the Indian Muslim minority sought the protection of democratic politics and the secular state. Their national identification was with secular India, not with Pakistan, 'the homeland for Muslims'. This was relatively successful in the Congress period, but with the electoral success of the BJP, Muslims have been increasingly marginalized. This has so far culminated in the Citizenship Amendment Act (CAA) and the National Register of Citizens (NRC), which, in asking people to prove their citizenship, is clearly targeted at the Muslim population (see Ahmad and van der Veer, this volume).

Muslim-Hindu antagonism is one of the major facts in Indian politics. The Partition was a clear case of religious purification, affecting Hindus, Muslims and Sikhs alike. The mobilization around religion, or, as Bob van der Linden (2008) prefers to call it, 'moral languages', was an integral part of emerging nationalism in nineteenth-century India. This also entailed attempts to purify language and other forms of cultural communication such as music (see van der Linden, this volume). Religion is 
part of the great transformation of Indian society into the nation form, but it should not be essentialized as a static core of the new identities. Also in Iran (see Alinejad in this volume) we can see that secular nationalism takes on religious elements, while religious nationalism takes on secular elements. In Jingyang Yu's contribution to this volume, one sees how language and religion are interwoven in the construction of ethnic identity among Chinese immigrants in Berlin. Religion does not have a stable meaning separate from contrastive concepts such as magic, spirituality and secularity that belong to the same conceptual universe. They emerge historically together, imply one another and function as nodes within a shifting field of power. This 'syntagmatic chain' occupies a key position in nationalist imaginings of modernity.

As Stefan Binder (this volume) argues, Indian secularism is not irreligious. This raises the question what place atheism has in Indian culture. Binder examines two recent Indian movies, $O h M y$ God and $P K$, which show the atheist as either a failure or an extraterrestrial alien. His readings of these media texts show the impossibility of atheism within the framework of the dominant discourses of religious nationalism and Indian secularism. Atheism in India and elsewhere is often aligned with a strong critique of inequality and a belief in science (see Binder 2020). Communism has been the most potent political expression of atheism. While in India communism has remained relatively marginal, in China it has become the dominant ideology.

Chinese atheist campaigns have targeted the 'superstition' of popular forms of religion, as well as the 'foreignness' of Christianity and Islam. Since Islam has become the primary target of the Chinese 'War on Terrorism', Protestants try to show their patriotism by joining efforts to convert Muslims (see Jie Kang in this volume). In her earlier work, Kang (2017) has already shown the effects of urbanization on making Protestantism a viable option for upwardly mobile, educated young Chinese. Here she demonstrates how Chinese Protestantism joins the internationalizing fervour of the 'One Belt, One Road Initiative'. Such fervent patriotism is also the spirit of Liu Cixin's immensely popular science fiction, which heralds China's global technological superiority. Jeroen de Kloet's essay in this volume analyses the blockbuster movie Wandering Earth, which is loosely based on Liu Cixin's story. China 
catching up with the world had been the aspiration of previous decades, but now it has become surpassing the rest of the world. The question of comparison often turns on the question of original and copy, but it is more productive to examine cultural interaction and translation. Today Chinese comparison with the West turns into futuristic competition, well expressed in Liu Cixin's science fiction.

One can also find these cultural transformations on the ground in Chinese society. The struggle against inequality, which led to large-scale land reform in the 1950s, has given way to the emergence of industrial entrepreneurship with huge aspirations to become rich overnight. While the hard labour of the rural worker has been the symbol of communist China, money has replaced its position as the universal signifier in the nationalist imagination. As Xiao He (this volume) argues, it is money, not equal citizenship, that mediates the nation. This is evident in the extent to which rural migrants to the city are excluded from urban services and opportunities.

If China is what Xiao He calls an 'investor's utopia', that utopia is primarily a technological future. China's contemporary 'technological capitalism', which doubles as 'surveillance capitalism' (Zuboff 2019), ushers in a digital future for the nation state. In the Chinese nationalist imagination, the digital economy is where China will overtake the West. Samuel Lengen (this volume) argues that Alibaba's digital ecosystem aims to unify the Chinese nation. By doing so, it also separates China from the rest of the world as a self-contained universe with its own technological aspirations and inequalities under the control of the state.

This volume demonstrates the various ways in which nationalism penetrates all fields of social action. Nationalism especially expresses itself in discursive productions of the 'Self' in relation to 'the Other', be it Protestant versus Catholic, Shi' ite versus Sunnite, Hindu versus Muslim, Chinese versus Western or 'secular liberated' versus 'religious repressed'. Creative explorations of the national 'Self' take place in religion, literature, cinema and even science (Sleeboom 2004). Such exploration can create sublime beauty, but in its shadow always lurks danger, fear and violence. The nationalist quest for purity produces enemies both within the fold and outside it. By striving for unification, it creates inimical difference on a global scale. 
Despite the image of rationality and enlightenment that have dominated social thought from Max Weber to Charles Taylor, societies are still what used to be called 'tribal', built on blood and territory. Societies continue to perform rituals of purification to exercise sovereignty. To understand that, one does need anthropology, the discipline best suited to provide some understanding of our chaotic world. The assumptions of rational choice, the big data that one can put into probability models and the fixation on neuroscience are all deficient when dealing with the symbolism of birth, death and purity. Artistic creation can sometimes represent these realities, make us feel their presence, but it is not able to elucidate the underlying cultural logic. This act of translation of lifeworlds by the anthropologist does not make something alien legible to an elusive 'us', it makes 'us' more legible to ourselves. It makes us see that we are not different, not more rational and no more capable than those who knock on our doors. It makes us understand that we might be the next ones to knock on doors, and that our desire to keep the doors locked stems precisely from this fear.

I want to thank my former students who contributed to this volume. I am especially grateful to Irfan Ahmad and Jie Kang who did the hard work of editing it. I have derived much pleasure from reflecting on the issues raised in the volume.

\section{References}

Ahmad, Irfan. 2009. Islamism and Democracy in India. Princeton: Princeton University Press.

Anderson, Benedict. 1991. Imagined Communities. London: Verso.

Anderson, Perry. 2021. Ever Closer Union? London: Penguin.

Binder, Stefan. 2020. Total Atheism. Secular Activism and the Politics of Difference in South India. Berghahn: Oxford.

Casanova, Jose. 2006. Secularization Revisited: A Reply to Talal Asad. In Powers of the Secular Modern. Talal Asad and His Interlocutors, ed. David Scott and Charles Hirschkind, 10-23. Palo Alto: Stanford University Press.

2019. Asian Catholicism, Interreligious Colonial Encounters and Dynamics of Secularism in Asia. In The Secular in South, East, and Southeast Asia, ed. Kenneth Dean and Peter van der Veer, 13-37. Cham: Palgrave. 
Gellner, Ernest. 1983. Nations and Nationalism. Oxford: Blackwell.

Habermas, Jürgen. 2012. The Crisis of the European Union: A Response. Cambridge: Wiley.

Kang, Jie. 2017. House Church Christianity in China. Cham: Palgrave.

Meyer, Birgit, and Peter van der Veer, eds. 2021. Refugees and Religion. London: Bloomsbury.

Müller, Jan-Werner. 2016. What is Populism? Philadelphia: University of Pennsylvania Press.

Sleeboom, Margaret. 2004. Academic Nations in China and Japan. London: Routledge.

Snyder, Timothy. 2010. Bloodlands: Europe Between Hitler and Stalin. New York: Basic Books.

Streeck, Wolfgang. 2017. How will Capitalism End? Essays on a Failing System. London: Verso.

Terpstra, Nicholas. 2015. Religious Refugees in the Early Modern World. Cambridge: Cambridge University Press.

Van der Linden, Bob. 2008. Moral Languages from Colonial Punjab: The Singh Sabha, Arya Samaj and Ahmadiyah. Delhi: Manohar.

Verkaaik, Oskar. 2004. Migrants and Militants. Fun and Urban Violence in Pakistan. Princeton: Princeton University Press.

Zuboff, Soshana. 2019. The Age of Surveillance Capitalism. London: Profile.

Open Access This chapter is licensed under the terms of the Creative Commons Attribution 4.0 International License (http://creativecommons.org/licenses/ by/4.0/), which permits use, sharing, adaptation, distribution and reproduction in any medium or format, as long as you give appropriate credit to the original author(s) and the source, provide a link to the Creative Commons licence and indicate if changes were made.

The images or other third party material in this chapter are included in the chapter's Creative Commons licence, unless indicated otherwise in a credit line to the material. If material is not included in the chapter's Creative Commons licence and your intended use is not permitted by statutory regulation or exceeds the permitted use, you will need to obtain permission directly from the copyright holder.

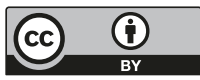

